\title{
HARMONY
}

\section{PENTINGNYA PERAN NILAI-NILAI PANCASILA TERHADAP KARAKTER REMAJA PADA ERA GLOBALISASI DAN DISRUPSI}

\section{Aulia Nuha An’Umillah ${ }^{\bowtie}$ Supriyono, Dadi Mulyadi Nugraha}

Indonesia University of Education

\begin{tabular}{l}
\hline Info Artikel \\
\hline Sejarah Artikel: \\
Disubmit: April 2021 \\
Direvisi: Mei 2021 \\
Diterima: Mei 2021 \\
\hline Keywords: \\
Values, Pancasila, \\
Globalization, Disnution,
\end{tabular}

\begin{abstract}
Abstrak
Globalisasi dan disrupsi kini kian menjamur, tak dipungkiri bany akny a buday a-buday a juga kebiasaan luar yang masuk ke dalam negeri. Remaja adalah faktor terbesar yang dapat dipengaruhi dengan mudah, terlebih pada reamaja awal. Maka patut ditanamkannya dan memahami apa saja nilai-nilai Pancasila juga maknanya pada remaja, agar kokoh terpatri dalam dirinya ideologi Pancasila. Menerapkanny a selalu dan membiasakan diri, tak hanyaitu peran disrup si tak selamany a buruk. Tetapi ketika menggunakan teknologi, dapat pula dengan ide-ide kreatif untuk menjangkau remaja dalam mengenalkan nilai-nilai Pancasila. Ide-ide kreatif tersebut bermaksud cara-cara kreatif dalam teknologi, namun dengan tidak mengubah makna dari masing-masing nilai Pancasila tersebut. Tidak hanya memahami nilai-nilai Pancasila, karena bukti nyata dari di terapkannya nilai-nilai Pancasila dalam kehidupan seorang remaja sehingga menjadi sebuah kebiasaan yang baik. Peran keluarga juga berpengaruh dan harus mencerminkan nilai-nilai Pancasila. Bersama-sama menghadapi globalisasi dan disrupsi, sebagai remaja yang memiliki jiwa nasionalis dan patriotisme patut menggalakkan dan terus mempelajari nilai-nilai Pancasila.
\end{abstract}

\section{Abstract}

Globalization and disruption are now increasingly mushrooming, it is undeniable that many foreign cultures and customs have entered the country. Adolescence is the biggest factor that can be influenced easily, especially in early youth. So it is appropriate to instill and understand what the values of Pancasila are as well as their meaning for adolescents, so that they are firmly embedded in the Pancasila ideology. Always apply it and get used to it, not only that the role of disruption is not always bad. But when using technology, it can also come with creative ideas to reach adolescents in introducing Pancasila values. These creative ideas mean creative ways in technology, but without changing the meaning of each of the Pancasila values. Not only understanding the values of Pancasila, because it is clear evidence of the application of Pancasila values in the life of a teenager so that it becomes a good habit. The role of the family is also influential and must reflect the values of Pancasila. Together facing globalization and disruption, as teenagers who have a nationalist spirit and patriotism, they should promote and continue to study the values of Pancasila.

(C) 2021 Universitas Negeri Semarang

\footnotetext{
\} \text { Alamat korespondensi: }

Indonesia University of Education, Bandung Jawa Barat
}

E-mail: aulianuhau@upi.edu

ISSN 2252-7133

E-ISSN 2548-4648 


\section{PENDAHULUAN}

Permasalahan yang dihadapi remaja saat ini adalah budaya-budaya luar yang masuk ke dalam negeri, tidak hanya itu perkembangan zaman yang semakin maju ini sudah berganti kepada era disrupsi, menggantikan cara-cara konvensional menjadi serba mengandalkan teknologi. Jika diterima sisi baiknya saja dan dapat memfilter budaya-budaya luar yang masuk akan berdampak baik pada keselarasan hidup seseorang. Namun pada remaja yang masih tidak menentu akan tingkah laku atau karakter yang mereka punya dengan umur yang masih sebiji jagung, dapat dengan mudah dipengaruhi melalui berbagai jenis tontonan, gaya fashion, gaya hidup dan sebagainya. Pada masa yang maju ini, meniru sesuatu hal baru adalah tren yang harus diikuti terlebih pada budaya-buday a asing yang masuk karena globalisasi. Tidak melihat apakah itu hal yang benar sesuai dengan nilai-nilai Pancasila atau tidak, bahkan nekat melakukan apapun untuk sebuah kata viral, jika sesuatu itu menarik perhatiannya dan orang lain maka akan terus dilakukan. Menjadi terkenal adalah cita-cita yang sekarang digandrungi. Dengan bermodal laptop atau gadgetnya ini mereka dapat mengakses banyak sekali video, siaran, bacaan dengan mudah sekali. Untuk umur remaja adalah umur yang sedang mencari, seoang remaja akan mengeksplor semua keingintahuan mereka akan sesuatu dan negatifnya dapat terbawa arus dengan mudah tanpa dilandasi dengan nilai-nilai Pancasila yang sudah sejak dulu diajarkan.

Penting sekali bahwa nilai-nilai Pancasila ini di implementasikan kedalam kehidupan seseorang, terlebih dalam pengembangan karakter seorang remaja. Dengan ideologi Pancasila maka sebagai warga negara yang baik harus mengamalkan nilai-nilai Pancasila dalam kehidupan sehari-hari, ideologi Pancasila tidak dapat terganti sampai kapanpun. Tugas warga negara yakni perlu melestarikan nilai-nilai yang terkandung dalam Pancasila dimulai sejak kecil hingga dewasa. Karena usia remaja adalah usia yang rentan maka sangat perlu ditegakkan nilai-nilai Pancasila tersebut agar tidak mudah dipengaruhi oleh ideologi lain selain Pancasila. Tujuan dalam penelitian ini adalah mengetahui apakah nilai-nilai memiliki peran penting dalam pembentukan karakter seorang remaja dalam era globalisasi dan disrupsi ini beserta saran yang akan dipaparkan kemudian.

\section{METODE}

Untuk mendukung penetilitian yang peneliti lakukan ialah menggunakan penelitian kuatitatif deksriptif, data disajikan melalui penjabaran deksriptif berupa angka persen. Untuk mendapatkan data primer, peneliti melakukan penyerbaran angket atau kuesioner yang mendapakan 90 responden remaja sebagai subjek topik yang diangkat, dan didapatkan 90 sampel dari semua jawaban responden. Ketika semua sampel sudah terkumpul, analisis dilakukan juga dukung beberapa buku referensi dan jurnal sebagai penunjang memperkuat penelitian.

\section{PEMB AHASAN}

\section{Pancasila Sebagai Dasar Negara}

Pancasila yakni mengandung makna bahwa nilai-nilai Pancasila dijadikan sebagai landasan dan juga pedoman dalam penyelenggaraan negara. Menurut Muzayin (1992:16), dengan Pancasila Indonesia akan terhindar dari perpecahan, Pancasila menjadi pandangan yang bertumpu pada pola hidup didasarkan pada kesimbangan, keserasian, keselarasan sehingga perbedaan dapat dibina menjadi sebuah pola kehidupan dinamis dengan keanekaragaman dalam satu keseragaman yang kokoh. Dengan adanya Pancasila ini menjadikan semua warga negara berlaku adil dan tidak membeda-bedakan dalam hal agama ataupun dalam suku ras. Sebagai satu kesatuan yang memiliki pandangan hidup yang sama, juga tujuan cita-cita yang sama kedepannya untuk saling membangun bangsa bersama-sama. Misalnya dalam masyarakat membantu bergotong-royong membersihkan lingkungan 
bersama-sama itupun sudah menerapkan nilai Pancasila dari sila ke dua sehingga dapat diindikasikan bahwa Pancasila sudah menjwai dalam kehidupan masyarakatnya. Kaelan (2000: 197) menyebutkan yakni pandangan hidup yang jelas bangsa Indonesia mempunyai pegangan dan pedoman untuk bagaimana mengenal, memecahkan bermacam-macam masalah seperti masalah politik, sosial budaya, ekonomi dan hukum. Serta masalah-masalah lainnya dalam gerak masyarakat yang semakin terus maju kedepannya. Maka pengaktualisasian dalam mengatasi masalah atau bahkan dapat mengantisipasi masalah yang datang pada masa globalisasi dan disrupsi ini. Banyak fenomena perubahan yang terus-menerus terjadi dikalangan masyarakat terlebih pada remaja yang ingin bebas berekspresi, jika dibiarkan maka akan tidak terarah sesuai dengan nilai-nilai Pancasila agarcara pandangnya tetap berpegang teguh pada Pancasila.

\section{a. Pentingnyanilai-nilai Pancasila dalam era globalisasi dan disrupsi}

Tabel 1. Pentingnya nilai-nilai Pancasila

\begin{tabular}{cc}
\hline Kategori & Persentase \\
\hline Ya & $100 \%$ \\
Tidak & - \\
\hline
\end{tabular}

Sumber: penelitian 2021.

Dalam mendapatkan data untuk penelitian ini, dilakukannya penyebaran kuesioner kepada 90 responden dengan hasil tabel yang sudah dilampirkan. Berdasarkan masalah penting atau tidakkah nilai-nilai Pancasila dalam era globalisasi dan disrupsi ini dapat dilihat bahwa dari 90 responden seluruhnya mencapai $100 \%$ dalam angket memilih penting untuk subbab ini. Tak ada tanggapan tidak dalam kuesioner ini, maka mereka, yakni remaja mengakui bahwa memang penting nilai-nilai dari Pancasila tersebut.

Terlihat jelas bahwa sangat penting sekali akan nilai-nilai Pancasila pada era globalisasi dan disrupsi yang makin mencekam keberadaannya, berbagai prinsip atau ideologi lain berdatangan seiring berkembangnya zaman ini. Namun sangat penting mengingat bahwa Pancasila dijadikan sebagai ideologi dan nilainilainya diambil dari kepribadian bangsa Indonesia sendiri. Lalu pentingnya nilai-nilai Pancasila di tengah majunya zaman merupakan peran penting dimana globalisasi yang semakin menjamur seakan batas negara tidak terlihat. Ini mengakibatkan masuknya budaya-budaya asing dan dapat mempengaruhi karakter seorang remaja, lajunya perkembangan teknologi juga membuat tercabutnya kebudayaan asli yang membahayakan eksistensi kepribadian bangsa Indonesia, pada akhirnya akan menjadi ancaman terhadap ketahanan nasional dan identitas bangsa. Memperkokoh pendirian bangsa ini sangat diperlukan, meskipun baik untuk memiliki sikap menghormati dalam menerima suatu budaya baru ataupun hal baru, namun pendirian kokoh kita harus ditegakkan melihat apakah sesuatu yang baru itu sesuai atau tidak dengan nilai-nilai Pancasila yang ada, dengan memfilter hal-hal baru yang masuk sehingga terhindarnya asimilasi. Sila-sila Pancasila pada hakikatnya adalah satu kesatuan, tidak lebih dari landasan falsafah bangsa, sehingga sila Pancasila adalah sistem nilai. (Kaelan dan Zubaidi, 2007: 31). Karena itu nilainilai Pancasila dijadikan sebagai pandangan hidup bangsa Indonesia, maka nilai-nilai dari serangkaian nilai-nilai itu adalah ketuhanan, kemanusiaan, persatuan, kerakyatan dan yang terakhir keadilan. Membahas lebih lanjut nilainilai yang terdapat dalam Pancasila adapun sebagai berikut:

\section{Ketuhanan Yang Maha Esa}

Nilai-nilai yang terdapat dalam sila pertama yakni sebagai warga negara atau sebagai manusia kita harus menjalani perintah Tuhan yang Maha Esa, wajib menjalankan segala perintah dan menjauhi larangan yang Tuhan larang untuk dilakukan. Untuk para remaja ini sebaiknya dijalankan dengan sebaik mungkin, karena tidak hanya menjadi warga negara yang baik akhlaknya, tetapi juga warga negara yang patuh terhadap Tuhan. Begitu pula 
meningkatkan toleransi terhadap perbedaan agama, tidak saling mengolok ataupun menjelekjelekkan agama yang lain. Karena adanya kebebasan terhadap HAM yang bebas memilih agama manapun untuk dianutnya.

\section{Kemanusiaan yang Adil dan Beradab}

Pada sila kedua memiliki nilai-nilai yang dimana sebuah negara menjunjung tinggi harkat dan martabat manusia sebagai makhluk yang beradab (Kaelan dan Zubaidi, 2007 : 32). Sebagai seorang warga negara wajib sekali mematuhi segala norma-norma yang berlaku, juga sebagai warga negara ini memiliki derajat yang sama untuk saling menjaga untuk mencapai kedamaian negara.

\section{Persatuan Indonesia}

Sila persatuan mempunyai nilai yang hakikatnya adalah satu, sebagai warga negara wajib bersatu meskipun terdiri dari banyaknya suku dan ras. Dari beraneka ragam itu menyatu dalam satu kesatuan dan didukung dengan semboyan Bhineka Tunggal Ika.

4. Kerakyatan yang Dipimpin oleh Hikmat Kebijaksanaan dalam

Permusyawaratan/Perwakilan

Sebagai warga negara patut memahami nilai-nilai yang terdapat dalam sila keempat, yakni tidak boleh memaksakan kehendak kepada orang lain, kemudian ketika ada sebuah permasalahan wajib diselesaikan dengan demokrasi melalui musyawarah mengambil keputusan bersama hingga mencapai mufakat, maka wajib juga bagi seorang warga negara menanamkan sikap saling menghargai.

\section{Keadilan Sosial bagi Seluruh Rakyat Indonesia}

Sila kelima ini terkandung nilai keadilan makmur yang merata pada seluruh rakyat Indonesia, bersikap adil dengan menyeimbangkan hak dan kewajiban diri juga dengan orang lain dan saling bergotong-royong membantu sesamanya.

Setelah melihat apa saja nilai-nilai yang terdapat pada sila Pancasila, perlu diketahui bahwa tak ada nilai yang memiliki tujuan tidak baik untuk warga negara, terlebih pada remaja. Ini sangat berpengaruh baik jika diimplementasikan pada kehidupan remaja, jika dibedah lebih dalam lagi terkait nilai-nilai Pancasila pasti banyak nilai-nilai yang baik pula Pada masa sekarang globalisasi berpengaruh pada nilai-nilai Pancasila, globalisasi adalah modernisasi tingkat lanjut sehingga globalisasi ini menyebarnya kebiasaan-kebiasaan keseluruh dunia, perluasan hubungan dengan lintas benua dan sebagainya. Globalisasi ini berhakikat mengglobal yang menyatukan seluruh perhatian manusia seluruhnya bersamaan, ini dapat memiliki dampak yang baik juga buruk. Namun pada masa globalisasi ini sebagai seorang remaja menyikapi dampak dari globalisasi tidak sesuai dengan nilai-nilai Pancasila dapat menyikapinya dengan selektif, sebagai remaja pun harus memiliki filter terhadap hal-hal baru yang masuk ke dalam negeri. Dapat memilah-milih mana yang perlu diikuti atau tidak, selalu berpegang teguh pada nilai-nilai Pancasila ketika menemukan hal yang baru. Entah itu dalam gaya busana ataupun kebiasaan sosial yang ketika tidak sesuai dengan nilai-nilai Pancasila, lebih baik tidak mengukuti atau menolak dengan tegas karena sudah jelas tidak sesuai dengan kepribadian bangsa yang ada tercantum dalam nilai-nilai Pancasila. Lebih baik tidak mengikuti agar tidak terjerumus dan selalu memahami serta mempraktekkan nilai-nilai Pancasila meskipun hal paling kecil sekalipun dalam kehidupan sehari-hari. Karena seorang remaja boleh mengenal budaya apapun atau hal baru apapun tetapi tetap berpegang teguh dan mengingat akan pentingnya nilai-nilai Pancasila, selalu berperilaku baik menyikapinya dengan tepat.

Dengan adanya era disrupsi sekarang ini cara-cara untuk mempertahankan nilai-nilai Pancasila agar tidak tergilas atau tidak hilang ini 
dengan banyak sekali cara. Perkembangan teknologi internet ini bisa menjadi salah satu solusi karena kontribusi besar yang telah mengubah pola interaksi rakyat yakni perkembangan internet telah mengubah masyarakat, perusahaan dan juga pemerintah. Maka semua elemen masyarakat pemerintah harus berkontribusi untuk mempertahankan nilai-nilai Pancasila, tidak hanya mempertahankan tetapi juga menjalankan nilainilai Pancasila. Meskipun dari hal kecil karena ketika memupuk dikit demi sedikit untuk mengimplementasikan nilai-nilai Pancasila dalam kehidupan maka akan terbiasa sendiri nantinya. Karena kemajuan teknologi zaman sekarang yang semakin maju menuntut agar individu harus kreatif dan inovatif kedepannya, maka untuk menggalakkan nilai-nilai Pancasila dapat melalui media yang menarik sesuai dengan perkembangan teknologi masa kini namun tetap berpegang pada nilai-nilai Pancasila seutuhnya dengan kata lain membuat konten menarik berisikan nilai-nilai Pancasila juga bagaimana contoh action dalam mempraktekkan nilai-nilai Pancasila tersebut.

Meskipun kemajuan teknologi semakin maju terus mengglobal tetapi harus tetap untuk menanamkan nilai-nilai Pancasila itu sendiri dan memanfaatkan teknologi dengan benar dan positif. Dalam menanamkan nilai-nilai pada diri, seorang individu harus memiliki jiwa nasionalisme agar dapat lebih memahami nilainilai Pancasila dan juga itu adalah sebuah kewajiban sebagai warga negara dan ketika sudah menerapkannya tidak lupa juga untuk melestarikannya mempertahankan agar tidak tergilas oleh kemajuan teknologi selalu mengingatkan orang-orang sekitar agar tetap menjalankan nilai-nilai Pancasila dengan sikap dan penuh rasa tanggung jawab. Maka sudah sepatutnya untuk diimplementasikan pada kehidupan sehari-hari sebagai pembentuk karakter untuk menanamkan jiwa nasionalisme dan patriotisme agar tidak luntur dan terus memaknai Pancasila.

\section{b. Nilai-nilai Pancasila memiliki peran terhadap karakter remaja}

Nilai-nilai Pancasila memiliki peran dalam pembentukan karakter seorang remaja ini dapat dilihat dari analisis remaja ini dapat dilihat dari analisis bahwa nilai-nilai Pancasila memiliki peran dalam pembentukan karakter, karakter ini karakter yang berlandaskan dengan nilai-nilai Pancasila.

Tabel 2. Nilai-nilai Pancaasila memiliki peran

\begin{tabular}{cc} 
dalam pembentukan & karakter remaja \\
\hline Kategori & Persentase \\
\hline Ya & $97,8 \%$ \\
Tidak & $2,2 \%$ \\
\hline
\end{tabular}

Sumber: penelitian 2021.

Dapat dilihat berdasarkan data yang diperoleh yakni $97,8 \%$ mengatakan bahwa nilainilai Pancasila memiliki peran sedangkan 2,2\% nya mengatakan tidak mengatakan tidak. Persentase yang didapat sudah bagus, seperti pada poin diatas yang sudah menjabarkan nilainilai Pancasila tak ada nilai-nilai Pancasila yang menunjukkan tujuan yang tidak baik, pada usia remaja ini merupakan usia pada tahap mencari jati diri cenderung mengedepankan ego dalam bertindak sesuai keingintahuannya maka perlu sekali ditanamkan nilai-nilai yang baik dalam dirinya salah satunya nilai-nilai Pancasila. Untuk menjadi sebuah individu yang baik dalam pembentukan karakter harus mendapatkan halhal yang baik, pula melakukan hal baik. Pada beberapa orang yang menjawab tidak memang nilai-nilai Pancasila tidak dapat dilakukan ketika seorang individu itu tidak memiliki keinginan untuk mengimplementasikannya, maka perlunya kesadaran untuk memaknai Pancasila agar dapat mengimplementasikan nilai-nilai Pancasila sebagai tujuan menjadi karakter moralitas remaja yang beradab. Adapun perannya seperti dapat menjadi kontrol perilaku agar dapat bersikap dengan baik, dapat berlaku sesuai dengan norma yang berlaku di masyarakat, penanaman jati diri bangsa, pembentuk karakter yang lebih baik, dan lain sebagainya. 


\section{c. Pemahaman akan nilai-nilai Pancasila}

Dalam mendapatkan data untuk penelitian ini, dilakukannya penyebaran kuesioner kepada 89 responden dengan hasil tabel pada bawah ini. Presentase ini menunjukkan bagaimana pemahaman yang dirasakan oleh remaja akan nilai-nilai Pancasila.

Tabel 3. Nilai-nilai Pancaasila memiliki peran dalam pembentukan karakter remaja

\begin{tabular}{cc}
\hline Kategori & Persentase \\
\hline Paham & $80 \%$ \\
Tidak Paham & - \\
Mungkin Paham & $20 \%$ \\
\hline Sumber: penelitian 2021
\end{tabular}

Terdapat $80 \%$ dari 72 remaja yang mengisi kuesioner ini sudah paham akan nilainilai Pancasila, remaja yang tidak paham berjumlah 0 , dan mungkin paham atau dengan kata lain mereka masih meragukan pemahaman mereka tentang nilai-nilai Pancasila yang mereka ketahui sebesar $20 \%$ dari 18 orang. Pada pertanyaan pertama tentang pemahaman akan nilai-nilai Pancasila dirasa sudah cukup mengerti terhadap maksud dari semua nilai-nilai Pancasila, tetapi akan lebih baik untuk lebih memahami kembali agar tidak ada keraguan akan nilai-nilai Pancasila terdapat apa saja didalamnya. Maka perlu untuk adanya pengenalan lebih dalam terkait nilai-nilai Pancasila kepada remaja, banyak sekali cara untuk mengenalkan secara luas. Perlu diketahui juga dalam mengenalkan terlebih pada era globalisasi dan disrupsi ini dapat melalui caracara yang disukai remaja saat ini. Dapat melalui sosialisasi yang disebarluaskan melalui internet atau media sosial dan televisi. Menggalakkan lewat konten-konten menarik yang menayangkan aksi dari pengimplementasian nilai-nilai Pancasila itu, karena untuk zaman sekarang ini diperlukan pendekatan yang lebih ekstra kepada remaja yakni harus masuk ke dalam dunia mereka terlebih dahulu. Menggunakan globalisasi teknologi dan disrupsi ini kearah yang lebih positif untuk mengenalkan nilai-nilai Pancasila agar lebih menjangkau remaja. Disamping itu dalam lingkungan keluarga, sekolah, perguruan tinggi pun mempengaruhi sehingga perlu contoh nyata juga dalam lingkungan tersebut meskipun hal kecil sekalipun, sehingga dapat terbentuk secara perlahan. Tak lupa pula untuk literasi terusmenerus tentang kewarganegaraan ataupun tentang pancasila, sehingga seorang remaja mempunyai pedoman untuk berpikir atau bertindak dalam kehidupan sehari-harinya dengan berlandaskan nilai-nilai Pancasila, maka terbentuklah jiwa kebangsaan yang kokoh dan terhindar dari hal-hal negatif serta selalu berpikir positif.

\section{SIMPULAN}

Berdasarkan penelitian yang telah dilakukan pada 90 responden dapat diambil kesimpulan terhadap peran dari nilai-nilai Pancasila terhadap karakter remaja di era globalisasi dan disrupsi ini sangat penting, terdapat $100 \%$ responden mengisi kuesioner dengan jawaban ya untuk pentingnya menerapkan nilai-nilai Pancasila ditengahtengah zaman yang semakin berkembang. Teknologi maupun globalisasi tidak dapat mengilangkan nilai-nilai Pancasila dari bangsa ini. Perlunya penyaringan terhadap hal-hal baru, berpikir kreatif namun tidak melupakan nilainilai Pancasila dalam berkarakter seorang remaja. Nilai-nilai yang terdapat dalam sila Pancasila adalah 1) Ketuhanan, 2) Kemanusiaan, 3) Persatuan, 4). Kerakyatan, dan 5) Keadilan. Nilai-nlai Pancasila memiliki makna masing-masing, maka tak perlu diragukan lagi bahwa nilai-nilai ini memiliki tujuan yang baik terhadap karakter seorang remaja nantinya akan berjiwa nasionalis dan selalu memaknai Pancasila dengan baik Adapun peran nilai-nilai Pancasila ini pada karakter seorang remaja seperti kontrol perilaku agar dapat bersikap dengan baik, dapat berlaku sesuai dengan norma yang berlaku di masyarakat, penanaman jati diri bangsa, pembentuk karakter yang lebih baik, dan lain sebagainya masih lebih banyak lagi. Dan pada permasalahn tentang pemahaman dari nilai-nilai 
Pancasila pada remaja pada hasil penelitian menunjukkan angka $80 \%$ untuk yang sudah paham dan $20 \%$ untuk yang masih ragu, angka ini menunjukkan angka cukup, namun alangkah baiknya untuk menggali lagi tentang nilai-nilai Pancasila itu terdapat apa saja, sebagai remaja dapat mempelajari kembali tentang nilai-nilai Pancasila tersebut. Namun diperlukan juga usaha untuk mengenalkan nilai-nilai Pancasila kepada remaja dengan menggunakan teknologi yang dapat menarik perhatian remaja dengan kemajuan teknologi sekarang. Lalu tidak hanya mengenalkan tetapi melakukannya juga sebagai contoh bentuk nyata agar semua remaja turut aktif dalam perwujudan nilai-nilai Pancasila itu sendiri dalam lingkup keluarga maupun sekolah atau perguruan tinggi. Pancasila sangat mempengaruhi aspek dalam setiap kehidupan agar menjadi sesuai dengan pandangan banga, juga agar melestarikan nilai-nilai Pancasila ini agar tidak tergeser dengan ideologi manapun. Maka Pancasila ini sangat penting dan patut untuk dimaknai bagi remaja.

\section{DAFTAR PUSTAKA}

Kaelan, \& Zubaidi, Ahmad. 2007. Pendidikan Kewarganegaraan untuk Perguruan Tinggi. Yogyakarta: Paradigma

Martono, Nanang. 2011. Sosiologi Perubahan Sosial :Perspektif Klasik, Modern, Posmodern, dan Poskolonial. Jakarta: Rajawali Pers

Tim Dosen Pendidikan Pancasila UPI. 2019. Pendidikan Pancasila. Bandung: CV Maulana Media Grafika

Kristiono, N. (2017). Penguatan Ideologi Pancasila Di Kalangan Mahasiswa Universitas Negeri Semarang. Harmony, 2(2), 193-204

Asmaroini, Puji Ambiro. 2016. Implementasi Nilai-Nilai Pancasila Bagi Siswa Era Globalisasi. Jurnal Pancasila dan Kewarganegaraan. 4 (2). 443-445

Octavian, W. A. (2018). Urgensi Memahami dan Mengimplementasikan Nilai-Nilai Pancasila dalam Kehidupan Sehari-Hari Sebagai Sebuah Bangsa. Bhinneka Tunggal Ika, 5(2), 123-128. 